\title{
Screening for Pompe disease in a Portuguese high risk population
}

\author{
Vânia Almeida a,1,*, Isabel Conceição ${ }^{a}$, Isabel Fineza ${ }^{b}$, Teresa Coelho ${ }^{c}$, Fernando Silveira ${ }^{\text {, }}$ \\ Manuela Santos ${ }^{\mathrm{e}}$, Ana Valverde ${ }^{\mathrm{f}}$, Argemiro Geraldo ${ }^{\mathrm{g}}$, Ricardo Maré ${ }^{\mathrm{h}}$, Teresa Carolina Aguiar ${ }^{\mathrm{i}}$, \\ Carla Mendonça ${ }^{\mathrm{j}}$, João Martins ${ }^{\mathrm{k}, 2}$, Luísa Medeiros ${ }^{1}$, Cândida Barroso ${ }^{\mathrm{a}, \mathrm{k}}$, José Pedro Vieira ${ }^{\mathrm{m}}$, \\ Teresa Moreno ${ }^{\mathrm{n}}$, Luis Negrão ${ }^{\mathrm{g}}$, Margarida Silva Dias ${ }^{\circ}$, Lúcia Lacerda ${ }^{\mathrm{p}}$, Teresinha Evangelista ${ }^{\mathrm{a}, 3}$ \\ a Serviço de Neurologia, Hospital de Santa Maria (Centro Hospitalar de Lisboa Norte, EPE), Av. Professor Egas Moniz, 1649-035 Lisboa, Portugal \\ ${ }^{\mathrm{b}}$ Sector de Neuropediatria-CDC, Hospital Pediátrico (Centro Hospitalar Universitário de Coimbra), Av. Afonso Romão, 3000-602 Coimbra, Portugal \\ ${ }^{\mathrm{c}}$ Unidade Clínica de Paramiloidose, Centro Hospitalar do Porto, Largo Prof. Abel Salazar, 4099-001 Porto, Portugal \\ ${ }^{\mathrm{d}}$ Centro Hospitalar de São João, Alameda do Professor Hernâni Monteiro, 4200-319 Porto, Portugal \\ e Serviço de Neuropediatria, Centro Hospitalar do Porto, Largo Prof. Abel Salazar, 4099-001 Porto, Portugal \\ ${ }^{\mathrm{f}}$ Serviço de Neurologia, Hospital Fernando da Fonseca, IC 19, 2720-276 Amadora, Portugal \\ ${ }^{\mathrm{g}}$ Serviço de Neurologia, Centro Hospitalar e Universitário de Coimbra, Praceta Prof. Mota Pinto, 3000-075 Coimbra, Portugal \\ ${ }^{\text {h }}$ Serviço de Neurologia, Hospital Braga, Sete Fontes - São Victor, 4710-243 Braga, Portugal \\ i Serviço de Neurologia, Centro Hospitalar do Funchal, Av. Luís de Camões, Funchal, Madeira 9004-514, Portugal \\ j Serviço de Neurologia, Hospital de Faro (Centro Hospitalar do Algarve), R. Leão Penedo, 8000-386 Faro, Portugal \\ ${ }^{\mathrm{k}}$ Serviço de Neurologia, Hospital Egas Moniz (Centro Hospitalar de Lisboa Ocidental), Rua da Junqueira 126, 1349-019 Lisboa, Portugal \\ ${ }^{1}$ Unidade de Neurofisiologia Clínica, Hospital de São José (Centro Hospitalar de Lisboa Central), Rua José António Serrano, 1150-199 Lisboa, Portugal \\ ${ }^{m}$ Serviço de Neurologia, Hospital Dona Estefânia (Centro Hospitalar de Lisboa Central), Rua Jacinto Marto, 1169-045 Lisboa, Portugal \\ ${ }^{n}$ Unidade de Neuropediatria, Hospital de Santa Maria (Centro Hospitalar de Lisboa Norte, EPE), Av. Professor Egas Moniz, 1649-035 Lisboa, Portugal \\ - Serviço de Neurologia, Hospital dos Capuchos (Centro Hospitalar de Lisboa Central), Alameda de Santo António dos Capuchos, 1169-050 Lisboa, Portugal \\ ${ }^{\mathrm{p}}$ Centro de Genética Médica Doutor Jacinto Magalhães (Centro Hospitalar do Porto), Praça Pedro Nunes, n. 88, 4099-028 Porto, Portugal
}

Received 1 November 2016; received in revised form 30 January 2017; accepted 24 March 2017

\begin{abstract}
Pompe disease is a rare metabolic disorder with available enzymatic replacement therapy. Contrasting with the classic infantile form, the others subtypes have a heterogeneous presentation that makes an early and accurate diagnosis difficult. We conducted a prospective, multicenter, observational study to identify undiagnosed patients. During a one-year period, patients followed in Portuguese neuromuscular outpatient clinics with proximal muscle weakness affecting upper and/or lower limbs, hyperCKemia in two or more determinations or hypotonia and hyperCKemia, were screened for acid $\alpha$-glucosidase deficiency by dried blood spots. Lysosomal acid-alpha-1,4-glucosidase activity was determined by tandem mass spectrometry and positive results were confirmed by molecular study. From the 99 patients screened, Pompe disease was confirmed in 4 , with age of onset ranging from 2.5 to 48 years, all with limb girdle muscle weakness, corresponding to a frequency of $4 \%$ in our cohort and $4.9 \%$ of limb girdle muscle weakness. Screening for Pompe disease in high risk populations, using dried blood spots, was already performed in some European populations. Apart from two negative Scandinavian studies, positive cases were confirmed in $2.8-7.9 \%$ of patients presenting with limb girdle muscle weakness and in $0-2.5 \%$ with isolated hyperCKemia.
\end{abstract}

(C) 2017 Elsevier B.V. All rights reserved.

Keywords: Pompe disease; High risk population screening; Dried blood spot; Acid $\alpha$-glucosidase deficiency

\footnotetext{
* Corresponding author: Hospital Vila Franca, Estrada Nacional N1, Povos, 2600-009 Vila Franca de Xira, Portugal. Fax: +351 263006636.

E-mail address: vnia.almeida@gmail.com (V. Almeida).

${ }^{1}$ Unidade de Neurologia, Hospital Vila Franca, Estrada Nacional N 1, Povos, 2600-009 Vila Franca de Xira, Portugal.

2 Serviço de Neurologia, Hospital Pedro Hispano (Unidade Local de Saúde de Matosinhos), Rua Dr. Eduardo Torres, 1164-513 Senhora da Hora, Portugal.

3 The John Walton Muscular Dystrophy Research Centre, Institute of Genetic Medicine, Newcastle University, Centre for Life, Newcastle NE1 3BZ, England, United Kingdom.
}

\section{Introduction}

Pompe disease (PD), glycogen storage disease type II, is a rare autosomal recessive metabolic disorder caused by deficiency of the lysosomal enzyme acid-alpha-1,4-glucosidase (GAA). The dysfunction of this enzyme leads to glycogen accumulation mainly in skeletal, cardiac and smooth muscles $[1,2] . \mathrm{PD}^{1}$ is classically

1 Pompe disease. 
divided in infantile $\mathrm{PD}^{1}$ and late onset PD (LOPD). The classic infantile form is characterized by hypotonia, progressive weakness, hypertrophic cardiomyopathy, hepatomegaly, macroglossia and respiratory failure [2]. There are also cases of infants presenting with muscle weakness and respiratory failure but without significant cardiomyopathy, corresponding to the non-classic infantile $\mathrm{PD}^{1}$ subtype. The more common $\mathrm{LOPD}^{2}$ has a heterogeneous presentation and may present from childhood to late adulthood with slowly progressive axial and/or limb-girdle muscle weakness, with or without respiratory symptoms; isolated respiratory failure or isolated hyperCKemia [2].

The heterogeneity of $\mathrm{LOPD}^{2}$ makes its diagnosis difficult and usually with a large delay from signs/symptoms onset [3]. The availability of a specific treatment since 2006 warrants a correct and early diagnosis of this condition [2].

Screening of high risk populations using dry blood spot (DBS) has been shown to be a reliable method to identify patients who will benefit for this diagnostic investigation and reveal phenotypes previously unrelated to $\mathrm{PD}^{1}$ [4].

We conducted a prospective, multicenter, observational study to identify undiagnosed $\mathrm{PD}^{1}$ in patients followed in Portuguese neuromuscular outpatient clinics using $\mathrm{DBS}^{3}$ as screening method.

\section{Patients and methods}

Screening for $\mathrm{PD}^{1}$ was part of a national, multicenter, prospective, observational study (ENDOMUS) promoted by Portuguese Society for study of Neuromuscular Disorders (SPEDNM), intended to study selected neuromuscular disorders in the Portuguese population. During the preparatory phase, the study was publicized in several national neuromuscular meetings to encourage the inclusion of as much centers as possible.

The patients were recruited from neuromuscular outpatient clinics during one-year-period, between February 2010 and January 2011. The inclusion criteria were: proximal muscle weakness affecting upper and/or lower limbs (limb girdle muscle weakness, LGMW), hyperCKemia in $\geq 2$ determinations or hypotonia and hyperCKemia. Patients were included if previous diagnostic workout (clinical evaluation, biochemistry, genetics, muscle biopsy and EMG) failed to give a definitive diagnosis.

For each patient, the demographic data, clinical history, neurological examination and laboratorial studies (biochemistry, muscle biopsy, EMG, previous molecular studies) were registered in an electronic case report form.

A $\mathrm{DBS}^{3}$ was obtained in each patient to measure the lysosomal GAA ${ }^{4}$ activity by tandem mass spectrometry, using 4-methylumbelliferyl- $\alpha$-D-glucoside as substrate and acarbose as inhibitor of maltase-glucoamylase. Blood samples were collected according to the reference laboratory instructions (Centro de Genética Médica Jacinto Magalhães). Equivocal

\footnotetext{
${ }^{2}$ Late onset Pompe disease.

${ }^{3}$ Dried blood spot.

${ }^{4}$ Acid-alpha-1,4-glucosidase.
}

$\mathrm{GAA}^{4}$ activity, due to insufficient blood sample or borderline GAA enzyme results, was repeated in a second DBS assay by request of the laboratory. For patients with abnormal enzymatic activity, a blood sample was collected and sent to the reference laboratory to confirm the diagnosis of $\mathrm{PD}^{1}$ by molecular study.

The protocol fulfilled the recommendations of the GCP and ethical principles deriving from the Declaration of Helsinki. The study was approved by the Ethics Committee of each center involved. The electronic case report form meets the legal requirements of the Portuguese Law for data protection. Informed consent was obtained from all patients, or from parents when appropriate.

\section{Results}

During the study period, 99 patients were included from 13 Portuguese centers. There was a slight female predominance (58\%), with a mean age of 36.1 years (range 3-80y); 28 patients were under 18 years $(28.3 \%)$. Twenty-four patients had positive family history for neuromuscular disorders.

The mean age at symptom onset was 24.9 years, ranging from congenital to 78 years. Half of the patients had disease onset in childhood or adolescence and $16 \%$ in the first year of life. The mean disease duration before the inclusion was 15.3 years (range 3-64 y).

Most patients presented with a phenotype of LGMW with or without hyperCKemia and only $18 \%$ as isolated hyperCKemia. Symptoms or signs of respiratory involvement were present in $21.4 \%$ and paraspinal muscle weakness was reported in $27.7 \%$. Seventy-two percent of the patients had CK levels at least 2 times the upper limit of normal. EMG was performed in 73 patients and showed a myopatic pattern in $71.3 \%$. In the 75 patients with muscle biopsy, about half of them had dystrophic changes and in 7 the report was suggestive of glycogenosis.

Definitive molecular diagnosis of $\mathrm{PD}^{1}$ was made in 4 patients (Table 1) from different centers. One patient had positive family history for neuromuscular disorder. All patients presented with $\mathrm{LGMW}^{5}$, corresponding to $4 \%$ of our cohort and $4.9 \%$ of patients presenting with LGMW. $\mathrm{PD}^{1}$ patients were Caucasian, $75 \%$ male, with age of onset of symptoms ranging from 2.5 to 48 years (mean $22.6 \mathrm{y}$ ). The mean time to diagnosis was 19.8 (range 10-42 y).

Respiratory involvement and paraspinal muscle weakness were present only in the two older patients with disease onset in adulthood. CK was mildly elevated in all patients $(2.7-5$ times the upper limit of the normal) and EMG showed myopathic pattern in the two cases performed. Muscle biopsy was performed in all patients but only in one was suggestive of glycogenosis. In other patient muscle biopsy had dystrophic changes with immunohistochemistry showing weak and irregular dystrophin staining. Dystrophinopathy was excluded by molecular study before inclusion in the study. Two ragged red fibers and some

\footnotetext{
${ }^{5}$ Limb girdle muscle weakness.
} 
Table 1

Demographic and clinical features of the new cases of Pompe disease.

\begin{tabular}{|c|c|c|c|c|c|c|c|c|c|c|c|c|}
\hline $\begin{array}{l}\text { Age at } \\
\text { symptoms } \\
\text { onset }\end{array}$ & Gender & $\begin{array}{l}\text { Limb } \\
\text { weakness }\end{array}$ & $\begin{array}{l}\text { Paraspinal } \\
\text { weakness }\end{array}$ & $\begin{array}{l}\text { Muscle } \\
\text { atrophy }\end{array}$ & Myalgia & $\begin{array}{l}\text { Respiratory } \\
\text { symptoms }\end{array}$ & $\begin{array}{l}\text { Other } \\
\text { symptoms }\end{array}$ & CK & $\begin{array}{l}\text { GAA activity } \\
\text { (pmol/punch/h) }\end{array}$ & EMG & $\begin{array}{l}\text { Muscle } \\
\text { biopsy }\end{array}$ & GAA mutations \\
\hline 2.5 & Male & $\begin{array}{l}\text { Scapular } \\
\text { girdle }\end{array}$ & No & Yes & No & No & - & 4.1 & 0.56 & - & Glycogenosis & $\begin{array}{l}\text { c. }-32-13 \mathrm{~T}>\mathrm{G} \\
\text { c. } 445 \mathrm{~A}>\mathrm{C} \text {; p. T149P* }\end{array}$ \\
\hline 4 & Female & $\begin{array}{l}\text { Pelvic } \\
\text { girdle }\end{array}$ & No & No & No & No & - & 2.7 & 0.11 & Myopathic & Inconclusive & $\begin{array}{l}\text { c. }-32-13 \mathrm{~T}>\mathrm{G} \\
\text { c. } 1153 \mathrm{delC} \\
\text { p.R385fsX39* }\end{array}$ \\
\hline 36 & Male & $\begin{array}{l}\text { Scapular and } \\
\text { pelvic girdle }\end{array}$ & Yes & Yes & No & $\begin{array}{l}\text { Respiratory } \\
\text { failure }\end{array}$ & $\begin{array}{l}\text { Dysphagia, } \\
\text { facial palsy, } \\
\text { atrial } \\
\text { fibrillation }\end{array}$ & 3.6 & 0.35 & - & Dystrophic & c. $-32-13 \mathrm{~T}>\mathrm{G}$ (homo) \\
\hline 48 & Male & $\begin{array}{l}\text { Scapular and } \\
\text { pelvic girdle }\end{array}$ & Yes & Yes & Yes & Orthopnea & $\begin{array}{l}\text { Left } \\
\text { ventricular } \\
\text { hypertrophy }\end{array}$ & 5 & 0.12 & Myopathic & Inconclusive & $\begin{array}{l}\text { c. }-32-13 \mathrm{~T}>\mathrm{G} \\
\text { c. } 1153 \mathrm{delC} \text {; } \\
\text { p.R385fsX391* }\end{array}$ \\
\hline
\end{tabular}

CK levels are present as times upper limit of normal.

GAA activity: acid-alpha-1,4-glucosidase activity. Reference values: 4.51-32.7 (pmol/punch/h).

* New mutation according to Erasmus MC GAA gene mutations database.

fibers with autophagic vacuoles were also described in this biopsy. One patient had also left ventricular hypertrophy and other had facial weakness, dysphagia and atrial fibrillation at the date of the study. The common c.-32-13T>G GAA gene mutation was present in all patients, but two new mutations were also found (one of them in two patients).

\section{Discussion}

$\mathrm{PD}^{1}$ is a rare metabolic disorder that apart from the less frequent classic infantile form that has a typical clinical presentation, has a variable age of onset, form of presentation, severity and rate of disease progression [1]. The clinical manifestations of $\mathrm{LOPED}^{2}$ overlap with other neuromuscular disorders, mainly muscle dystrophies, but also include atypical clinical features as isolated respiratory failure or non-muscular symptoms such as scoliosis, hearing impairment and arrhythmia [5]. Some red flags for the diagnosis of $\mathrm{PD}^{1}$ have been proposed as the disproportionate axial and respiratory muscle involvement, in comparison with limb muscle weakness, the presence of mild non-dystrophic myopathic features on muscle biopsy and mild CK elevation (usually below 1000) [6]. Muscle biopsy may reveal excess of glycogen with positive periodic acid-Schiff material in muscle fibers or vacuoles, EMG may show very often myotonic discharges, particularly in paraspinal muscles, but these features are not universally present.

The introduction of enzyme replacement therapy with alglucosidase alpha has increased the general awareness of this disease [3], but diagnosis delay is significant and estimated to be around 7 years from signs/symptoms onset in LOPD ${ }^{2}$ [7]. Although an accurate and early diagnosis of $\mathrm{LOPD}^{2}$ is difficult to achieve, early treatment was reported to be associated to a better efficacy of the therapy [4].

DBS $^{3}$ has been successfully used to screen for $\mathrm{PD}^{1}$ and is suggested to be the optimal initial diagnostic test, followed by biochemical assays on a different tissue and/or genetic analysis to confirm positive cases [5]. Two $\mathrm{DBS}^{3}$ techniques are currently available, fluorometry and tandem mass spectrometry, both with consistent results [5].

Estimated worldwide incidence of all forms of $\mathrm{PD}^{1}$ is 1 in 40,000 live births [1,5], but several studies showed that incidence rate may vary among different ethnic populations, ranging from 1:14,000 in an African American population to 1:600,000 in a Portuguese population [7]. There are some data that permit estimate the prevalence of $\mathrm{PD}^{1}$ in Caucasian to $1-2: 100,000$ [7]. It is known that $\mathrm{PD}^{1}$ is very rare in Scandinavia [8].

We used $\mathrm{DBS}^{3}$ to screen patients followed in Portuguese neuromuscular clinics with undetermined LGMW $^{5}$ or hyperCKemia and found 4 new cases of PD (4\%). All patients presented with $\mathrm{LGMW}^{5}$, corresponding to a frequency of $4.9 \%$ in this phenotype. We did not found any case of $\mathrm{PD}^{1}$ in patients with hyperCKemia but this presentation corresponded only to $18 \%$ of our cohort. The delay in the diagnosis was almost 20 years. The age of onset was variable and the clinical features suggestive of $\mathrm{PD}^{1}$, as axial muscle weakness and respiratory symptoms, and muscle biopsy with a glycogen excess was not present in all our patients as previously reported in literature.

Screening for $\mathrm{PD}^{1}$ in high risk populations using $\mathrm{DBS}^{3}$ was already performed in some European populations (Table 2) both in neuromuscular and respiratory units [4-11]. Apart from one study that included only patients with asymptomatic or minimally symptomatic hyperCKemia (mild non-specific myalgia or mild fatigue) [4], the other cohorts included also cases of proximal weakness without a definitive diagnosis. In three studies, patients with myopathy and unspecific muscle biopsy $[6,8,9]$, and in one, patients with myopathic pattern in EMG [9], were also included irrespective of clinical presentation. The number of patients included varied from 82 in the western Sweden study to 3076 patients in the German and Britain cohorts, in a total of 4905 patients. 
Table 2

Review of studies screening for Pompe disease in high risk populations.

\begin{tabular}{|c|c|c|c|c|c|}
\hline Country & $\mathrm{N}$ & Inclusion criteria & Phenotype & $\begin{array}{l}\text { Prevalence (total and } \\
\text { according to phenotype) }\end{array}$ & $\begin{array}{l}\text { Mean time to } \\
\text { diagnosis (years) }\end{array}$ \\
\hline Portugal, 2016 & 99 & $\begin{array}{l}\text { - LGMW } \\
\text { - HyperCK } \\
\text { - Hypotonia and HyperCKemia }\end{array}$ & $\begin{array}{l}\text { LGMW + hyperCK: } 52 \% \\
\text { LGMW: } 30 \% \\
\text { HyperCK: } 18 \%\end{array}$ & $\begin{array}{l}\text { Total: } 4 \% \\
\text { LGMW: } 4.9 \% \\
\text { HyperCK: } 0 \%\end{array}$ & 19.8 \\
\hline $\begin{array}{l}\text { Germany and United } \\
\text { Kingdom, } 2016 \\
{[10]}\end{array}$ & 3076 & $\begin{array}{l}\text { - LGMW } \\
\text { - HyperCK }\end{array}$ & $\begin{array}{l}\text { LGMW + hyperCK: } 76 \% \\
\text { HyperCK: } 24 \%\end{array}$ & $\begin{array}{l}\text { Total: } 2.4 \% \\
\text { LGMW + hyperCK: } 2.8 \% \\
\text { HyperCK: } 1.2 \%\end{array}$ & NR \\
\hline $\begin{array}{l}\text { Western Sweden, } \\
2016 \text { [8] }\end{array}$ & 82 & $\begin{array}{l}\text { - Unspecific LGMD or myopathy } \\
\text { - Abnormal muscle biopsy }\end{array}$ & $\begin{array}{l}\text { LGMW: } 26.7 \% \\
\text { Unspecific myopathy: } 73.2 \%\end{array}$ & 0 & - \\
\hline Spain, 2015 [7] & 348 & $\begin{array}{l}\text { - } \geq 18 \text { years } \\
\text { - Unclassified LGMD } \\
\text { - HyperCK }\end{array}$ & $\begin{array}{l}\text { LGMW: } 42 \% \\
\text { HyperCK: } 58 \%\end{array}$ & $\begin{array}{l}\text { Total: } 4.6 \% \\
\text { LGMD: } 7.5 \% \\
\text { HyperCK: } 2.5 \%\end{array}$ & 15 \\
\hline Spain, 2015 [11] & 241 & $\begin{array}{l}\text { - Unspecified myopathy } \\
\text { - HyperCK } \\
\text { - Polymyositis } \\
\text { - Control group }\end{array}$ & $\begin{array}{l}\text { Unspecified myopathy: } 26 \% \\
\text { HyperCK: } 32 \% \\
\text { c: } 12 \%\end{array}$ & $\begin{array}{l}\text { Total: } 3 \% \\
\text { Unspecified myopathy: } 3 \% \\
\text { Others: } 0 \%\end{array}$ & 17.5 \\
\hline Italy, 2016 [5] & 1051 & $\begin{array}{l}\text { - } \geq 5 \text { years } \\
\text { - LGMW } \\
\text { - HyperCK }\end{array}$ & $\begin{array}{l}\text { LGMW + hyperCK: } 40 \% \\
\text { LGMW: } 8 \% \\
\text { HyperCK: } 52 \%\end{array}$ & $\begin{array}{l}\text { Total: } 1.6 \% \\
\text { LGMD + hyperCK: } 2.6 \% \\
\text { LGMD: } 1.3 \% \\
\text { HyperCK: } 0.9 \%\end{array}$ & 5 \\
\hline Finland, 2014 [9] & 108 & $\begin{array}{l}\text { - Proximal myopathy } \\
\text { - Exercise intolerance and myalgia } \\
\text { - HyperCK } \\
\text { - Abnormal muscle histology } \\
\text { - Myopathic and/or myotonic EMG }\end{array}$ & $\begin{array}{l}\text { LGMW: } 51.9 \% \\
\text { Myalgia, exercise intolerance: } 31.5 \% \\
\text { Proximal and distal weakness: } 5.6 \% \\
\text { Rhabdomyolysis: } 4.6 \% \\
\text { Axial myopathy: } 1.6 \% \\
\text { Rigid spine: } 0.9 \%\end{array}$ & 0 & - \\
\hline Italy, 2013 [4] & 137 & - HyperCK & HyperCK: $100 \%$ & Total: $2.2 \%$ & - \\
\hline Denmark, 2013 [6] & 103 & $\begin{array}{l}\text { - } \geq 15 \text { years } \\
\text { - Unclassified LGMD } \\
\text { - HyperCK } \\
\text { - Myopathy on muscle biopsy } \\
\text { - Restrictive respiratory insufficiency } \\
\text { - Unspecified myopathy }\end{array}$ & $\begin{array}{l}\text { LGMW: } 36.9 \% \\
\text { HyperCK: } 15.5 \% \\
\text { Myopathy on muscle biopsy: } 3.9 \% \\
\text { Respiratory insufficiency: } 16.5 \% \\
\text { Unspecified myopathy: } 27.2 \% \%\end{array}$ & $\begin{array}{l}\text { Total: } 3.3 \% \\
\text { LGMW: } 7.9 \% \\
\text { Others: } 0 \%\end{array}$ & 9.3 \\
\hline
\end{tabular}

LGMW - limb-girdle muscle weakness; NR - not revealed; HyperCK - hyperCKemia.

Apart from two negative Scandinavian studies, positive cases were confirmed in all other cohort studies with regard to patients presenting with $\mathrm{LGMW}^{5}$ or isolated hyperCKemia. In patients with a limb girdle muscle dystrophy phenotype, $\mathrm{PD}^{1}$ was found with a frequency ranging from 2.8 to $7.9 \%$ and in isolated or paucisymptomatic hyperCKemia from 0 to $2.5 \%$. These differences in prevalence may be real and due to a different frequency of $\mathrm{PD}^{1}$ in different countries. However, we cannot exclude that some of the variation observed in the different studies is due to methodological bias.

DBS is increasingly recommended in the diagnostic work-up of patients with unclassified myopathies with proximal weakness as a useful tool to reach early diagnosis of $\mathrm{PD}^{1}[7,10]$. $\mathrm{DBS}^{3}$ assay for $\mathrm{PD}^{1}$ could also be considered in patients with asymptomatic or paucisymptomatic hyperCKemia as a simple instrument to exclude a treatable neuromuscular disorder.

\section{Acknowledgements}

Sanofi Genzyme Portugal provided financial support for the conduction of this study (AGLU07009IST) under the protocol entitled: "ENDOMUS- Caracterização Clínica e Diagnóstica de Doentes com Patologia Neuromuscular - Estudo Epidemiológico em Portugal”.
The authors wish to thank Sanofi Genzyme for assistance with manuscript preparation.

\section{References}

[1] Kishnani PS, Steiner RD, Bali D, Berger K, Byrne BJ, Case LE, et al. Pompe disease diagnosis and management guideline. Genet Med 2006;8:267-88.

[2] Dasouki M, Jawdat O, Almadhoun O, Pasnoor M, McVey AL, Abuzinadah A, et al. Pompe disease: literature review and case series. Neurol Clin 2014;32:751-76.

[3] Kishnani PS, Amartino HM, Lindberg C, Miller TM, Wilson A, Keutzer $\mathrm{J}$, et al. Timing of diagnosis of patients with Pompe disease: data from the Pompe registry. Am J Med Genet 2013;161A:2431-43.

[4] Spada M, Porta F, Vercelli L, Pagliardini V, Chiadò-Piat L, Boffi P, et al. Screening for later-onset Pompe's disease in patients with paucisymptomatic hyperCKaemia. Mol Genet Metab 2013;109:171-3.

[5] Musumeci O, la Marca G, Spada M, Mondello S, Danesino C, Comi GP, et al. LOPED study: looking for an early diagnosis in a late-onset Pompe disease high-risk population. J Neurol Neurosurg Psychiatry 2016;87:5-11.

[6] Preisler N, Lukacs Z, Vinge L, Madsen KL, Husu E, Hansen RS, et al. Late-onset Pompe disease is prevalent in unclassified limb-girdle muscular dystrophies. Mol Genet Metab 2013;110:287-9.

[7] Gutiérrez-Rivas E, Bautista J, Vílchez JJ, Muelas N, Díaz-Manera J, Illa I, et al. Targeted screening for the detection of Pompe disease in patients with unclassified limb-girdle muscular dystrophy or asymptomatic 
hyperCKemia using dried blood: a Spanish cohort. Neuromuscul Disord 2015;25:548-53.

[8] Lindberg C, Anderson B, Engvall M, Hult M, Oldfors A. Search for Pompe disease among patients with undetermined myopathies. Acta Neurol Scand 2016;133:131-5.

[9] Palmio J, Auranen M, Kiuru-Enari S, Löfberg M, Bodamer O, Udd B. Screening for late-onset Pompe disease in Finland. Neuromuscul Disord 2014:24:982-5.
[10] Lukacs Z, Nieves Cobos P, Wenninger S, Willis TA, Guglieri M, Roberts M, et al. Prevalence of Pompe disease in 3,076 patients with hyperCKemia and limb-girdle muscular weakness. Neurology 2016;87: 295-8.

[11] Pérez-López J, Selva-O'Callaghan A, Grau-Junyent JM, Gallego-Galindo L, Coll MJ, García-Morillo S, et al. Delayed diagnosis of late-onset Pompe disease in patients with myopathies of unknown origin and/or hyperCKemia. Mol Genet Metab 2015;114:580-3. 